Article

\title{
Sustainable Business Models of SMEs: Challenges in Yacht Tourism Sector
}

\author{
Cinzia Battistella ${ }^{1}$, Maria Rosita Cagnina ${ }^{2}$, Lucia Cicero ${ }^{1, *}$ and Nadia Preghenella ${ }^{1}$ \\ 1 Polytechnic Department of Engineering and Architecture, University of Udine, 33100 Udine, Italy; \\ cinzia.battistella@uniud.it (C.B.); nadia.preghenella@uniud.it (N.P.) \\ 2 Department of Economics and Statistics, University of Udine, 33100 Udine, Italy; \\ mariarosita.cagnina@uniud.it \\ * Correspondence: lucia.cicero@uniud.it; Tel.: +39-0432-558043
}

Received: 3 August 2018; Accepted: 18 September 2018; Published: 27 September 2018

check for updates

\begin{abstract}
Despite the high number of active small and medium enterprises (SMEs) in all sectors, current studies have barely developed investigations on the sustainability of their business models so far. The aim of this study was thus to bridge the gap between sustainable business models of SMEs in the service industry, to uncover the challenges that SMEs face when seeking business model reconfiguration toward sustainability. More specifically, the empirical investigation adopted a case study research design in the context of yacht tourism, as one business form among many within the tourism industry and thus within the broader category of the service industry. Interviews were conducted with seven European SMEs, whose business models were analyzed through the lens of the triple bottom line and sustainability challenges in their business models. The results display a varied typology of case studies, where business model components reveal diverse expressions of facing sustainability challenges. The work discusses reported findings with a cross-case comparison among detected business models and outlines a list of propositions for sustainable business models of SMEs. The paper contributes in continuing the discourse on sustainable business models, adopting the perspective of the challenges for SMEs and offers food for thought for managers of SMEs in comparing their own business with the identified business model types.
\end{abstract}

Keywords: sustainable business model; triple bottom line; yacht tourism; business model innovation; service industry; SMEs; case study research

\section{Introduction}

Many international institutions and governments have included sustainability in their programs as a fundamental element of the society of the future [1]. In 2008, in its report on sustainable development, the OECD (Organisation for Economic Co-operation and Development) argued that at "the core of sustainable development is the need to consider 'three pillars' together: society, the economy and the environment [...]. Social well-being and economic well-being feed off each other, and the whole game depends on a healthy biosphere in which to exist" [2] (p. 27).

All companies, both large and small and medium-sized enterprises (SMEs), are affected by sustainability issues and they are calling into question the responsibility assumption for their business activities, as well as the interrelated impacts on the environment and society. Although SMEs, taken individually, are smaller and have less impact on the environment than larger businesses, they represent $99.8 \%$ of all business in Europe [3] and about the $80 \%$ of all globally registered enterprises [4]. According to several scholars [5-7], SMEs collectively have a significant environmental and societal impact. Thus, SMEs should start adopting more sustainable behaviors and a long-term vision to design environmentally and organizationally sustainable processes [8]. 
While empirical evidence suggests that environmental and social factors have progressively become strategic concerns for larger companies, which are increasingly integrating sustainability matters into their corporate strategies, several studies have shown that SMEs lag behind in commitment to sustainable practices $[7,9,10]$. As highlighted by some scholars, this is explained by a variety of elements often related to the typical features of SMEs, which prevent them from implementing environmental and sustainable strategies. Such characteristics include limited financial and human resources [11,12], organizational structure and culture [13,14], management capabilities, and a lack of understanding of the benefits [15-17]. In addition, external barriers constrain SMEs, as for instance insufficient external drivers and incentives both from governments and from the marketplace, or the inadequacy and the complexity of formal environmental management tools, such as ISO 14001, are very expensive for SMEs [14]. Nevertheless, Moore and Manring [4] underline that the acceleration of technological innovation, the rapid markets change, the development and linkage of supply chain systems, and the spread of globalized communication networks, are going to gradually induce SMEs to introduce the practice of sustainable development.

Although research on sustainable business models is growing substantially in management studies and in the strategic and innovation management literature in recent years [18-20], how sustainable business models work in the real world, and what determines their success or not in the market, is a field still little explored; especially in SMEs and in contexts other than the manufacturing industry and supply chain management, where many SMEs are involved [21,22]. This means that, despite the significant efforts to enhance the knowledge of sustainable business models, many areas remain weak. The aim of this article was thus to contribute to bridging the gap on the knowledge of sustainable business models in SMEs in the service industry, and in tourism more specifically, highlighting the tensions that a SME could face when trying to reconfigure its business model toward sustainability.

The article is structured as follows. The next section examines the literature on sustainable business models, with a specific focus on challenges. This is followed by the research gap identification and research question statement. The methods used to analyze the case studies are then detailed: We selected seven SMEs in the yacht tourism industry and we identified by cross-case analysis three types of sustainable business models. An overview of each group of case studies is provided and the main findings of the research study are discussed through the examination of the triple dimensionality of sustainability (i.e., economic, social, and environmental) and its related challenges on sustainable business modelling (i.e., value proposition, value creation, and value capture). To conclude, managerial and academic implications, limitations of the research and future research indications are provided.

\section{Theoretical Background}

\subsection{Sustainable Business Models: Challenges}

Sustainable business models are defined as "business models that incorporate pro-active multi-stakeholder management, the creation of monetary and non-monetary value for a broad range of stakeholders, and hold a long-term perspective" [23] (pp. 403-404). Beyond underlining the clue importance of relationships with stakeholders and non-monetary value, other definitions [24-27] explicitly link the sustainability features over economic sustainability, though including both the environmental and the social dimensions.

According to Hart and Milstein [28], a sustainable enterprise takes part in sustainable development by delivering at the same time economic, social, and environmental benefits. The triple bottom line (TBL) approach $[29,30]$ puts in evidence how firms must focus not just on the economic value they add but also on the environmental and social one. More in details, according to Evans [31], economic value forms include profit, return on investments, financial resilience, long-term viability, and business stability. Social value forms embed equality and diversity, well-being, community development, secure livelihood, labor standards, and health and safety. Environmental value forms finally consist of the use of renewable resources, low emissions, low waste, biodiversity, and pollution prevention. 
Companies can shift from an unsustainable business model to a sustainable one based on innovation and on features such as: A set of ethic-based business principles; a strategic and sustainable management of natural resources; the sustainable production of natural, human, social, institutional, and cultural capital; a capacity to share these positive impacts in its supply chain [30]. Shifts into business models are acknowledged as a basic way to realize innovations for sustainability, whether they are based on small changes or radical innovations [31]. However, as the natural environment and society are considered as primary stakeholders and sustainable business models require a system of sustainable value flows among multiple stakeholders [31], this needs a change of mindset about business and the reconfiguration of many elements such as knowledge management, collaborations, relationships, and capabilities [32]. Moving to a new, sustainable business model is challenging for companies; these challenges differ along the three main components of the business model, namely value proposition, value creation and delivery system and value capture [33].

The first challenge is related to the value proposition of the business model innovation, i.e., finding business purposes and offerings that can guarantee a long-term competitive advantage. The innovative idea can derive from different sustainability inspirations, such as the circular economy, the sharing economy, eco-efficiency, inclusive business, the base of a pyramid and product-service systems [34]. Despite the multiplicity of possible value propositions, they have in common the aim of creating value through the integration of economic, environmental, and social aspects, rather than prioritizing profit and devoting to the society at large rather than only to the company itself $[20,26]$. However, the integration of such facets is tough, for the reason that economic, environmental, and social aspects can be conflicting to manage together [35] and since the focus on business logic still wins often against the focus on sustainability logic.

The second challenge is related to create value, i.e., developing a sustainable business model by means of specific practices, capabilities, and resources oriented to sustainability. In this line, a study by Bocken [36] opened the way to the conceptualization of a sustainable business model through the identification of eight sustainable business model archetypes. The archetypes describe solutions aimed at contributing to the development of sustainable business models, stressing the potential paths for sustainable business model innovation. The outlined archetypes are: Maximize material and energy efficiency; create value from waste; substitute with renewable and natural processes; deliver functionality rather than ownership; adopt a stewardship role; encourage sufficiency; re-purpose the business for society/the environment; develop scale-up solutions. These different archetypes represent different challenges in terms of value creation, involving practices, capabilities, and resources, such as organizational culture, corporate governance, operations, innovation and research and development, operations, supply chain and logistics, marketing and sales [34].

The third challenge is related to capture value from a sustainable business model: Technological, organizational, and social innovation factors [26] such as the use of renewable resources, flexible working and ethical trade [36], help organizations to bridge the design-implementation gap of sustainable business model innovation by capturing value from different actors such as shareholders/investors, employees, customers, suppliers/partners, society, environment, government and environment and also creating cascaded value for them [34].

The three challenges above are summarized in Table 1, which displays the challenges of creating sustainable value in business model innovation by proposing an adaptation from Evans [31]. 
Table 1. Challenges for creating sustainable value in business model innovation; adapted from Evans [31].

\begin{tabular}{|c|c|c|}
\hline & $\begin{array}{l}\text { Sustainable } \\
\text { Challenges }\end{array}$ & References \\
\hline & triple bottom line & \\
\hline $\begin{array}{c}\text { Value } \\
\text { Proposition }\end{array}$ & $\begin{array}{l}\text { integrating } \\
\text { technology } \\
\text { innovation with } \\
\text { business model } \\
\text { innovation }\end{array}$ & $\begin{array}{l}\text { Bocken et al. [36]; Hart and Milstein [28]; Heyes et al. [37]; } \\
\text { Joyce and Paquin [38]; Schaltegger et al. [24]; Stubbs and Cocklin [39]; } \\
\text { van Bommel [35]; Wells [40]; Yu and Hang [41]; Zott et al. [42] }\end{array}$ \\
\hline \multirow{3}{*}{$\begin{array}{l}\text { Value } \\
\text { Creation }\end{array}$} & mindset & \multirow{3}{*}{$\begin{array}{l}\text { Boons and Lüdeke-Freund [26]; Björkdahl and Holmén [43]; } \\
\text { Chesbrough [44]; Dentchev et al. [45]; Geissdoerfer et al. [46]; } \\
\text { Girotra and Netessine [47]; Halme and Korpela [48]; Heyes et al. [37]; } \\
\text { Lüdeke-Freund et al. [49]; Johnson et al. [50]; Joyce and Paquin [38]; } \\
\text { van Bommel [35]; Yang et al. [51]; Yu and Hang [41]; Zott et al. [42] }\end{array}$} \\
\hline & resources & \\
\hline & $\begin{array}{l}\text { business modelling } \\
\text { methods and tools }\end{array}$ & \\
\hline $\begin{array}{l}\text { Value } \\
\text { Capture }\end{array}$ & $\begin{array}{l}\text { external } \\
\text { relationships }\end{array}$ & $\begin{array}{l}\text { Boons and Lüdeke-Freund [26]; Dembek et al. [52]; Stubbs and Cocklin } \\
\text { [39]; van Bommel [35]; Vladimirova [53] }\end{array}$ \\
\hline
\end{tabular}

These challenges are tougher if sustainable business models are innovated in SMEs because these companies suffer already from other constraints, such as lacking an efficacy base of knowledge, skills, and resources whereby they can operationalize sustainable or green business practices [54]. Nowadays the adoption of a sustainable business model in SMEs may be very critical and challenging for SMEs having to overcome the obstacles due to their characteristics. In an article on environmental management practices for sustainable business models in SMEs in the hotel sector, Buffa [21] underline some elements to be taken into consideration in this process. Firstly, an SME cannot be considered as a "little big business" and therefore the strategic choices eligible for large firms may be unsuitable for an SME. Secondly, territorial inter-firms relationships are key factors in facing up to the complexity of the competitive environment. Finally, the velocity of the decision-making processes is the assurance of the flexibility in responding to market changes.

Finally, a discussion of sustainability efforts in the marketplace often concentrates around the manufacturing sector. However, the service industry is important because

Services have a catalytic role in sustainable social and economic development and serve as a means of addressing poverty, upgrading welfare, and improving the universal availability of and access to basic amenities. It can be argued that pursuing a sustainable development strategy is predicated on both the development and nurturing of domestic services sectors as well as engagement in international trade in services [55] (p. 3).

Certainly, a restaurant, a bank or a consulting firm do not have the environmental impact of a coal mine or automotive plant. Still, there are many opportunities for service-based businesses to engage in sustainability initiatives to boost profits, strengthen the community, and protect the environment. Furthermore, much variability in the service industry represents a difficulty compared with the manufacturing industry as it is difficult to provide one-size-fits-all recommendations on how to make a business model more sustainable.

\subsection{Research Gap}

The literature on sustainable business models of SMEs lacks a well-structured development. Indeed, only a few articles have focused on small-sized companies so far. Among the short list, a pertinent example is from Kozlowski [56]. The authors, through an empirical research, outlined the "reDesign canvas", a tool thought for micro-sized companies of the fashion industry with the aim of enhancing sustainability. In their canvas, blocks such as "circular design and economies", "innovative and sustainable business models", "design and smart material selection", and "sustainable supply 
chain" explicitly include elements of sustainable business modelling that could overspread other industries, by considering the peculiarities related to the reduced size of the company.

Differently, Gasbarro [57], by examining sustainability within the case of institutional entrepreneurship, identified a direct relationship between the final customer and strategic partnerships as instruments to increase legitimacy within the normative and cultural-cognitive institutions and subsequently in the regulative institutions. Other studies, despite covering the sustainability issue in business models, either focus on just one pillar (e.g., economic sustainability [58]; environmental sustainability [21]) or go into specific contexts, such as start-ups. For instance, Bocken [59] focused on the role that venture capitalists have on business model sustainability of start-ups according to the TBL, in particular in improving the balance of financial/social/environmental returns.

It follows that, from the review of sustainable business models, it emerges as a gap connected to the study of SMEs in general and on SMEs of the service/tourism/yacht industry more specifically. Indeed, for what concerns sustainable business models in services, predominant research has rather explored the manufacturing industry. Nonetheless, the main types of services described in the literature are the electricity and gas distribution sector e.g., References [60-66], the transport sector e.g., References [67-70] and the healthcare sector e.g., References [71-73]. The gap found in the literature is relevant both in terms of content, due to the small number of scientific articles retrieved, and in terms of methodology. Indeed, it seems that the empirical methodology in this area is still in its infancy. The research on sustainable business models of service companies is still undergoing the process of theory building and it is foreseeable that this process will continue for some years. At last, only when it will reach a higher level of maturity, it could be tested through surveys.

Therefore, we can say that the literature presents a gap of studies that deeply investigate business models and sustainability in the service industry; for this reason, attention may be paid to the specific field of tourism. The tourism sector could act as a place of study to be then extended to other sub-sectors within the service industry.

Even research on sustainability in tourism business models seldom emerge in former literature and, when it happens, it focuses mainly on the hospitality context [74-77]. The value proposition of tourism companies is analyzed according to the application of the TBL of the sustainable business model, although they detect limited monitoring of the three dimensions at a time and highlight the difficulties that companies face in revising the business model from the perspective of value creation [74,76,77]. Only Gretzel [78] has examined the role of technological innovation for value proposition, although in the context of tourism ecosystems. Other papers such as References [79-82], focused on the three pillars, although by highlighting the social aspects of sustainability specifically, with a great attention to the value created by sustainable tourism activities in the community. Capturing value through the development of key external relationships appears as an element for stimulating the progress towards a sustainable business model [77,83,84]. For instance, Høgevold [75] showed a case study of a Scandinavian hotel chain and how it dealt with the TBL of the sustainable business model, where a network of stakeholders and sourcing were key elements of business model innovation. It follows that challenging elements of sustainable business models in tourism still need further research to detect possible directions for concrete sustainable implementation.

In conclusion, a consistent research gap on sustainable business models has been detected from the literature review, as well as scholars calling for an in-depth examination of the interactions between existing business models and sustainable business models in practice [23], and by focusing on one sector/company specifically [45]. Moreover, we were interested in adopting a different perspective from the previous studies, thus following the calls for new research by Reference [23], we chose to focus on challenges for enterprises when adopting sustainable business models. Specifically, it could be meaningful to adopt an ad-hoc revision of one of the inspirational research questions proposed by Geissdoerfer [23] (i.e., "What are the challenges that an organization faces when creating new, sustainable business models?") (p. 410) as a prompt for our investigation. Our research question can be stated as follows: 
What are the challenges that a SME in the yacht tourism industry faces in adopting a sustainable business model or in modifying the existent business model toward a sustainable one?

\section{Materials and Methods}

In order to respond to the call of Geissdoerfer [23] and Evans [31] for further empirical investigation on sustainable business models, this research employed a multiple case study design for theory development [85]. Multiple cases were selected because they were proper for observing the phenomena in their complexity and consequently allowed a holistic and contextualized analysis, where not-previously known events could be important for comprehension and explanations [86-88]. We used the case study research design with a purposive sampling strategy with a variance theory approach, as defined by Patton [89] and Gioia [90], selecting cases that highlight practices that are not yet clearly stated or yet to be investigated by the literature, for in-depth research. To observe and compare patterns and logics of sustainable business models in the tourism sector, a deliberate theoretical sampling was performed for data collection [91]. Key criteria established to select cases were (1) being a yacht tourism enterprise (i.e., a marina) (2) being a SME (whose size was included in the parameters for micro or small enterprises according to the definition of European Union (European Commission Recommendation 2003/361). We decided to focus on marinas given their specificity for the theme of sustainability. We selected a sample of seven companies that was sufficiently heterogeneous in terms of location, juridical form, scope and main service activity. The main dimensions of differentiation were location and main activity. This has been done to ensure the presence of maximum variability within the primary data. It must be acknowledged that the yacht tourism industry was previously analyzed in order to detect the typology of enterprises operating in such business sector and the sample can be representative of the industry and country business specialization.

Table 2 shows evidence of the variation of criteria among the cases. Although anonymity may not be a desirable choice in case study reporting, it is justified when the aim of its use was the protection of the real cases in being recognized, as well as when the cases are illustrative for an ideal type [88]. Both situations are present in our study. Indeed, we faced the need to protect information on business facts and strategies by sample SMEs, which are not subject to publicity as bigger companies. Moreover, the case studies are reported for their illustrative purpose in connection with the theoretical framework on sustainable business model challenges by Evans [31]. Still, interviewees explicitly asked for case anonymity. With these premises, the case studies are presented in anonymity.

Table 2. Features of the case studies.

\begin{tabular}{|c|c|c|c|c|c|c|}
\hline Cases & Location & $\begin{array}{c}\text { Year of } \\
\text { Foundation }\end{array}$ & $\begin{array}{l}\text { Juridical } \\
\text { Form }\end{array}$ & $\begin{array}{l}\text { Firm Size } \\
\text { (Employees; } \\
\text { Turnover) }\end{array}$ & $\begin{array}{c}\text { Scope } \\
\text { (\% Foreign } \\
\text { Customers) }\end{array}$ & Main Activities \\
\hline Case A & Italy & 2003 & Private & $\begin{array}{c}\text { Small } \\
(10-49 ; € 2-10 \mathrm{~m})\end{array}$ & $\begin{array}{l}\text { International } \\
(40 \%)\end{array}$ & Repair and refit \\
\hline Case B & Italy & 1973 & Private & $\begin{array}{c}\text { Small } \\
(10-49 ; € 2-10 \mathrm{~m})\end{array}$ & $\begin{array}{l}\text { International } \\
(55 \%)\end{array}$ & Repair and refit \\
\hline Case C & Spain & 1983 & Public & $\begin{array}{c}\text { Micro } \\
(<10 ; € \leq 2 \mathrm{~m})\end{array}$ & $\begin{array}{l}\text { International } \\
(25 \%)\end{array}$ & $\begin{array}{l}\text { Berthing and } \\
\text { mooring rent }\end{array}$ \\
\hline Case D & Spain & 1952 & No-profit & $\begin{array}{c}\text { Micro-Small } \\
(10-49 ; € \leq 2 \mathrm{~m})\end{array}$ & Local & $\begin{array}{l}\text { Nautical courses } \\
\text { and sport activities }\end{array}$ \\
\hline Case E & Portugal & 1983 & No-profit & $\begin{array}{c}\text { Micro-Small } \\
(10-49 ; € \leq 2 \mathrm{~m})\end{array}$ & $\begin{array}{l}\text { International } \\
(50 \%)\end{array}$ & $\begin{array}{l}\text { Nautical courses } \\
\text { and sport activities }\end{array}$ \\
\hline Case F & Portugal & 1978 & Private & $\begin{array}{l}\text { Small-Medium } \\
(50-249 ; € 2-10 \mathrm{~m})\end{array}$ & $\begin{array}{l}\text { International } \\
(90 \%)\end{array}$ & Repair and refit \\
\hline Case G & Albania & 2017 & Private & $\begin{array}{c}\text { Micro-Small } \\
(10-49 ; € \leq 2 \mathrm{~m})\end{array}$ & $\begin{array}{l}\text { International } \\
\qquad(25 \%)\end{array}$ & Mooring rent \\
\hline
\end{tabular}




\subsection{Data Sources and Data Collection}

To maximize the validity and reliability [92], multiple sources of data were used, with the double aim to increase the information basis and to diversify it, implementing an information triangulation. In particular, the source channels for data were both primary sources (semi-structured interviews) and secondary sources (publicly available data from press reviews, websites, and archival documents provided by informants). Informants were selected among the key roles for sustainable business model development, such as the company $\mathrm{CEO}$, the person responsible for strategy, or the person responsible for sustainability. For each case, one interviewee was selected and a total of 7 face-to-face interviews were conducted. The collection of data required circa 21 non-consecutive days of on-site visits and the time-frame of the analysis was from December 2017 to March 2018.

To ensure coherence and consistency, and to guide the process of data gathering, an interview protocol was developed. This included both semi-structured and open-ended questions, in order to contextualize data collected to each specific area. Questions were formulated to investigate elements and managerial actions aimed at developing sustainable business models and possible obstacles and challenges in their implementation. Therefore, we organized them in the following sections and related topics of discussion:

- Company main information and history, highlighting the main disruptive events, business strategy and innovation strategy;

- $\quad$ sustainability: Economic impact, social impact, and environmental impact;

- physical resources; human resources and competencies; financial resources;

- network and supply chain (suppliers, customers, partnerships, and stakeholders);

- $\quad$ activities and quality;

- point of view on challenges, obstacles and future developments.

\subsection{Data Analysis}

Case analyses were conducted following the recommendations of several scholars [87,88,93,94]. Interview transcripts and archival data were analyzed following a two-step procedure, involving a within-case analysis and a search for cross-case patterns $[85,93]$ in terms of the main elements of sustainable business models and challenges. Figure 1 illustrates the data analysis process that is detailed afterwards.

A cross-case analysis was conducted in order to group SMEs according to recurrent patterns in their business models from the perspective of sustainability. A selection of variables based on the triple-layered business model canvas of Joyce and Paquin [38] was examined throughout the case studies to trace either commonalities or differences among business models, resulting into the identification of three types of business models. In particular, these variables were:

- Economic dimension: Technological innovation, the importance of technical skills, internationalization, networking, horizontal partnerships, vertical partnerships, facilities and infrastructures, quality orientation, customer relationship, marketing initiatives, use of social media;

- environmental dimension: Clean energy production, environmental certificates, reuse-recycle initiatives, technological innovation for the environment, initiatives for environmental awareness and education;

- social dimension: Social activities to schools, social activities to disabled or disadvantaged people, local community involvement, sponsorships.

The variables were expressions of the three dimensions of the TBL and, as such, useful to guide the analysis of sustainability challenges within the business models of the sample enterprises. The variables were detected within the primary and secondary sources of information for each case study at first and compared with each other. 


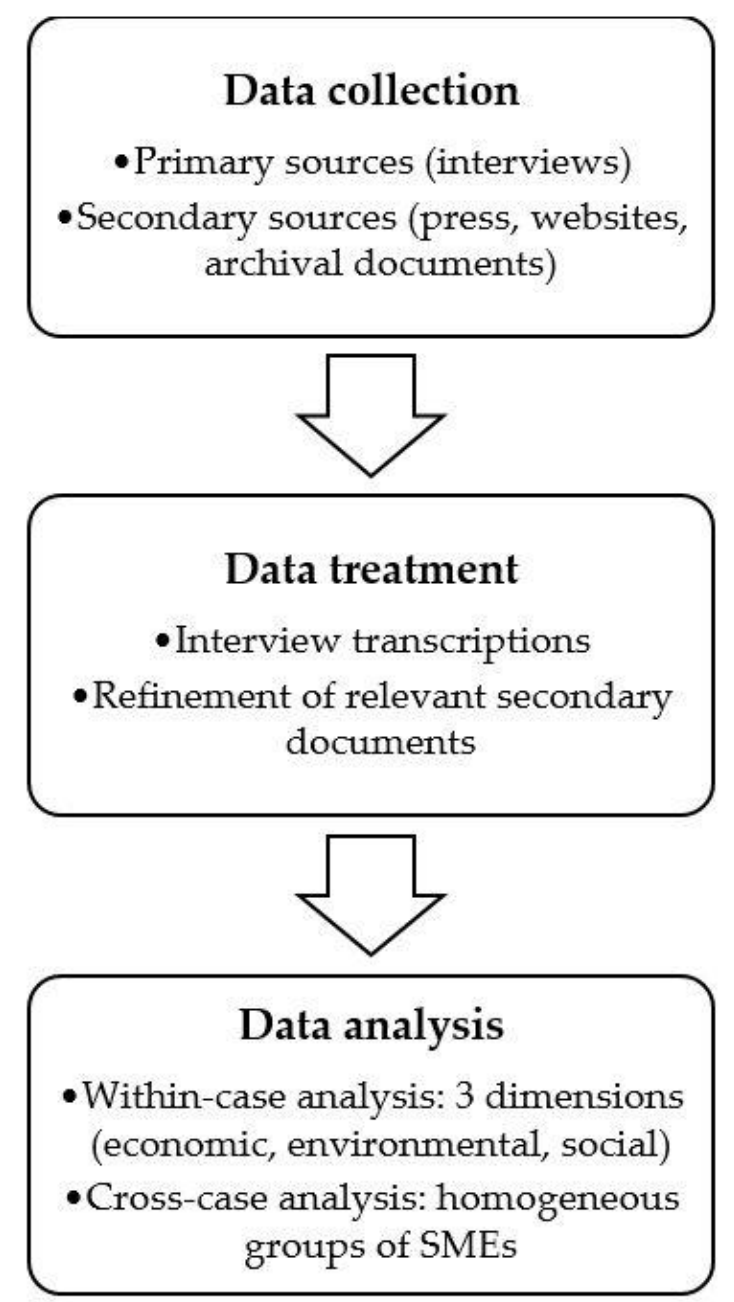

Figure 1. The data analysis process.

We used then the challenges for creating sustainable value in business model innovation suggested by Evans [31] to compare and describe the three groups. Moreover, given the qualitative nature of the study, to perform it in a rigorous way, two researchers autonomously (based on documents, interviews and observation) evaluated the case and wrote their comments, and subsequently shared their opinions to obtain a convergent assessment. Gaps and conflicts were resolved by further reviewing the transcripts and by consultation with interviewees. Finally, informants reviewed and confirmed the case results to ensure the investigators' comprehension was correct. Such feedback from informants was essential to prevent observer bias and establish the credibility of the interpretation [94].

\section{Results}

Challenges for sustainable business model creation have come to light from the literature review and are outlined in the theoretical background. A within-case analysis was performed to highlight the three dimensions of sustainability in each case. Table 3 reports the results of the analysis in the case studies. 
Table 3. Analysis of the three dimensions of sustainability of the case studies.

ID

The marina offers both nationals $(60 \%)$ and foreign $(40 \%)$ boat owners traditional shipbuilding and boat storage, as well as special areas in order to make the most of their free time and to relax. The company achieves success by creating strong relationships with suppliers that offer high-quality standards. Its main revenues depend on repair and refit services, followed by moorings' rents. Key resources consist of the strategic geographical position, green areas and expertise of artisans. Main investment is in the creation of commercial networks.

The marina offers an all-inclusive after-navigation service to leisure boat owners, who are both nationals (45\%) and foreigners (55\%). The company aims at establishing a direct relationship with final customers, relying on

B word-of-mouth and on the use of social media. Its main revenues depend include repair and boat transport machinery, moorings, and boat dry storage venue the main cost is staff.

The marina proposes a safe and fully equipped freshwater marina close to an important tourist destination. Boat owners are present all year long in the marina and considered as part of the family. Other customers are boat the marina and considered as part of the family. Other customers are boat enthusiasts during nautical fairs and events. Both customer segments

C contribute to the main revenues. Key activities rely on rent of moorings, repairing, as well as event organization and training. Key resources are moorings and dry berth venues, repair machinery, event venues, and other facilities, such as restaurants. The main cost is maintenance and dredging of the area.

The marina promotes nautical and water sports, establishing a relationship with local community mainly. Customers are athletes, sports practitioners and people interested in social aspects. A communication

D manager looks after social media and public profiles. Main revenues come from memberships and rent of moorings. Key activities are sports courses and maintenance of sports facilities, that are the main key resources. The marina is a partner of a national sectorial association, a national organization for social inclusion, and of several local associations.

The functional value is the number of boats repaired and maintained as well as boat owners served. Services and facilities are certified according to European and international directives that have allowed the company to obtain the Blue Flag recognition for sustainability and the environment. The company is environmentally managed according to UNI EN ISO 14001.2015 certification. The company also installed a photovoltaic system, LED systems, and a charging point for electric vehicles.

The functional value could be expressed in terms of moorings occupied and boat owners served.

The production phase adopts innovative technologies, when available. The company accomplishes with environmental law and puts into practice waste management initiatives.

The functional value could be expressed in terms of moorings occupied and event visitors. The marina site is recovering of an old dumping site. The marina accomplishes with waste management, recycling, and disposal of dangerous waste, aiming at a future ISO certificate. The marina promotes a second-hand market for the reuse of nautical accessories.
The social value is guaranteed through activities in schools and training opportunities for university students. The company is involved in the promotion of one local prize aimed at awarding professionals dealing with sea economy.

The social value is based on providing all-year work opportunities for local employees. Another initiative addressed to the local community is the dedicated provision of small-boat moorings to locals, despite minor revenues.
The functional value could be expressed in terms of a number of members and moorings occupied. The marina is engaged in improving constantly systems for water reuse and optimization, as well as clean energy production and save.
The social value is based on representing a meeting point for the local community. The marina is involved in local events and provides spaces to local associations. Recreational boating is seen as an opportunity for local development.

The social value is to foster the ethical and social sustainability and awareness. The marina promotes sports activities to local associations of people with disabilities and free activities for children with no means. Local associations promote events within the marina spaces. 
Table 3. Cont.

ID

The main goal of the marina is to promote nautical activities for both nationals $(50 \%)$ and foreigners $(50 \%)$. The company provides training fo

adults, as well as repair and maintenance services for boats. Its main revenues depend on repair and refit services, followed by moorings' rents. Key resources include a strategic geographical position, a specialized management style and lower prices; The main cost is staff.

The marina aims at delivering an "all-in-one-place" service to boat owner (90\% foreigners) and maritime authorities. Customers are considered as friends and the company relies on good reputation and service quality for acquiring new clients. Its main revenues depend on key activities of repair
and refit services. Key resources are concessions, moorings, repair and refit venues, own software to boat management. The marina is a partner of several marine-related companies, as well as a regional association for sea economy and a cluster of marinas; the main cost is staff.

The marina offers a variety of facility services to yacht owners, who are mainly national $(75 \%)$. The company is benefited by the infancy of

$G$ national marina market. The company leverages mainly on the price strategy. Its main revenues consist of moorings' rents. Key resources include an attractive location and high standard facilities.
The company accomplishes with all applicable garbage of paper, glass and oil (in appropriate oil containers). The waste is collected both in the port and in all facilities, ensuring subsequent recycling through authorized companies. environmental regulations. It selectively collects daily

With regard to social value, the company supports nautical sports programs that are provided free of charge to young people up to 18 years old, usually on the basis of collaboration agreements with local schools and local authorities (e.g., parishes, municipalities).

The functional value could be expressed in terms of moorings occupied and boat owners served. The company accomplishes with the highest environmental standards required by law and puts into practice a water recycling system.

The social value is based on providing all-year work opportunities for local employees. The marina continually collaborates with schools for training projects. The marina could be considered as a driver of the local tourism growth.

The functional value could be expressed in terms of moorings occupied. The company is engaged in activities like maintenance of local roads nearby business site and beach water cleaning. The company respects laws for the protection of the environment, sea and fauna.
With regard to social value, the marina is opened for visitors, students and tourists. The company implements a code of conduct for recruiting, training and maintaining a skilled workforce. The company supports neighboring schools with funds. 
A cross-case analysis was conducted in order to group yacht tourism SMEs (i.e., marinas) according to recurrent patterns in their business models from the perspective of sustainability. Sustainable business models have been interpreted through their three main components: Value proposition, related to business offerings that guarantee competitive advantage in the long term; the creation of value through specific sustainable practices, capabilities and resources; the value capture by using technologies, as well as organizational, and social innovation factors. A selection of variables was examined throughout the case studies to trace either commonalities or differences among business models, resulting in the identification of three types of business models. The following paragraphs describe the three types of sustainable business models following the principles of the triple-layered business model of Joyce and Paquin [38] (Section 4.1). Within each business model type, challenges on sustainable business model components (i.e., value proposition, value creation, and value capture) were detected and are described in Section 4.2.

\subsection{Business Model Typology of Yacht Tourism SMEs}

\subsubsection{Business Model for Maintenance-Focused Marinas}

The first identified business model groups private enterprises having maintenance of leisure boats as the core activity. This group is characterized by a strong attitude towards technological innovation. Leisure boat owners represent the main customer segment and embodied at least at $50 \%$ of international clients. Customers are frequently moved towards the marinas via word-of-mouth and the relationship between customers and the marinas is tight and strong, based on reliance, on high-quality service standards, guaranteed by the provision of quality suppliers and expert workers. Key activities for this business model are repair and refit activities for leisure boats, followed by the rental of moorings and berths. Both kinds of activities concur with revenue production. The geographical position of marina venues represents a strategic resource for this group of companies. Other key resources are spaces dedicated to specific functions: Maintenance areas (i.e., repair and refit venues), berth areas (i.e., moorings, boat dry storage hangars), and leisure areas (i.e., restaurants, green areas). A particularly relevant resource for this business model is the expertise of artisans working to maintain, repair, and refit leisure boats, either as direct employees of the enterprises or outsourced local workers. Machinery, concessions, and software are considered additional important resources in the business model of maintenance-focused marinas. Main costs are due to the employment of qualified workers. Networking is a clue activity for these companies, which aim at establishing horizontal partnerships mainly, for instance by belonging to marina clusters or regional associations of sea economy.

From the environmental point of view, the marinas appear to be highly involved in environmental care. They accomplish environmental regulation and waste management. Further environmental-focused initiatives include the achievement of ISO certificates or the Blue Flag award, clean energy production (i.e., photovoltaic systems), and resource-saving systems (i.e., energy saving or water recycling systems).

From the social perspective, this business model is focused on all-year work opportunities for local employees and in the promotion of local development through tourist arrivals. Moreover, companies involve local schools and universities into didactic activities and training projects.

\subsubsection{Business Model for Dock Marinas}

In this business model, the main activity is the rental of moorings to national boat owners, with international customers representing only the $25 \%$ of total clients. Loyalty plays an essential role in the relationship with customers, based upon the retention of leisure boat owners over the years. Other key activities include hosting and organizing events, as well as the provision of leisure facilities, such as restaurants. It follows that key resources consist of moorings, berths, commercial spaces, and event-dedicated infrastructures. The main costs are due to the maintenance of mooring areas, followed by costs related to other venues. No developed partnerships are reported. 
From the environmental point of view, the marinas are engaged in waste management and recycling. They are active in the care of the local environment surroundings, with initiatives aimed at the preservation of close areas and water bottoms.

From the social perspective, the activities of marinas are highly dedicated to the local community, promoting the marinas as meeting points for local people and visitors. Initiatives are developed for guaranteeing both skilled workforce and ethical behaviors. Sponsorships to local schools are carried out.

\subsubsection{Business Model for Sport-Oriented Marinas}

The third business model type groups no-profit companies, whose main focus is on the provision of facilities for sports activities, through the promotion and organization of sports courses and sports infrastructure. Customers are mainly national sport practitioners and leisure boat owners, interested in both sport and social opportunities. The relationship between customers and marinas is maintained directly, with additional support from communication-dedicated employees, for example by following the use of social media, although with a limited international scope. Key activities include the organization of sports courses, maintenance of sports infrastructure, and mooring rental. It follows that the main strategic resources are infrastructure facilities, including both mooring areas as well as sport and leisure spaces. The main costs are due to infrastructure maintenance and employment. Sport-oriented marinas appear as frequent developers of partnerships with sectorial and social associations. The latter relationship is strengthened by the joint organization and promotion of events within the marina spaces. Moreover, other partnerships are established with local authorities and schools.

Marinas accomplish waste management and recycling, including hazardous waste management. Systems of water reuse and optimization are developed and technologies aimed at energy saving and clean energy production are adopted.

From the social perspective, marinas are very active in developing social-oriented initiatives, such as the provision of free activities for children and young people with no means, usually realized through the joint collaboration with schools and local authorities. Moreover, marinas promote sports activities and events for disabled people and local associations.

\subsection{Challenges in Business Model Typology}

\subsubsection{Business Model for Maintenance-Focused Marinas}

The value proposition of this group of companies seeks an integration among the three components of the triple bottom line (i.e., economic, social, environmental), where technology innovation plays a key role in the business model. For instance, marinas are oriented towards energy efficiency and solar-power based energy innovation.

The value creation springs from the orientation towards quality, achieved through the selection of high-standard products and suppliers. Moreover, the expertise of qualified artisans supports the provision of top-quality services. Companies look for identification of such quality standards through the accomplishment of formalized indicators, such as ISO certificates or the Blue Flag award. Despite these efforts, companies in this group seem to lack a recognition of the importance of meticulous business modelling to improve the sustainability of their business.

Companies engage in extensive relationships with several stakeholders for capturing value aimed at both their own business and local development. Indeed, the cultivation of personal, direct, and strong relationships with customers is an activator for other tourism-related activities in the neighborhoods. In addition, local communities take advantage of work and training opportunities. 


\subsubsection{Business Model for Dock Marinas}

The value proposition of this business model lacks orientation towards the TBL. Economical aspects dominate both the social and the environmental attitudes, creating an unbalanced scenario. Indeed, environmental care is limited to basic initiatives and social features are restricted to a local scope. The role of technological innovation is almost absent in the business model and potential improvements by technologies are not minded in the business structure.

The design of value creation entails a traditional way of allocating resources, aimed at guaranteeing standard services for national customers. Few formalizations are referred to workforce management, although lack a structured mindset towards sustainable business modelling. A revision of the business model through a sustainability-driven perspective could stimulate a different resource allocation, rephrasing business objectives towards a sustainable orientation in the long term.

External relationships aiming at activating value capture are limited to local contacts, and, as such, have a limited impact on the business model sustainability. Extension of stakeholder's engagement through interaction could support the sustainable development of the business model.

\subsubsection{Business Model for Sport-Oriented Marinas}

The value proposition of these marinas seeks an integration of the three dimensions of the TBL, although the social aspects are especially relevant for their business model. Given the fact that they are no-profit companies, it is implied that economic profit is not their primary goal: The financial balance is sufficient for satisfying their economic requirements. Nonetheless, interest in environmental improvements is recognized and put into practice with the support of technological innovation. In more detail, waste management systems and resource saving systems (e.g., energy saving, water reuse) are the basis of their environment-concerned efforts.

Within the value creation feature, marinas are reluctant to adopt formalized tools for business modelling and improvement. Revenues are balanced with maintenance costs: No other business formulas are employed apart from the generation of necessary funds to invest in infrastructure maintenance. From a sustainability perspective, the adoption of technological innovations for environmental care activities implies resource allocation processes, which are able to positively impact on both company business and the local community.

Value capture through external relationships is developed through a thick net of partnerships with local associations, authorities, and schools. Companies generate extra value aimed at external beneficiaries, children, and young people in primis. Different stakeholders of the entire value chain are involved and taken into consideration to support the sustainability of marinas' business model.

\section{Discussion}

In the presentation of the theoretical background of this paper, we proposed a reinterpretation of the challenges for creating sustainable value in business model innovation proposed by Evans [31]. Table 4 shows the challenging aspects that appear in the business model typology emerging from our study, linking the previously outlined theoretical framework with the results of our research. 
Table 4. Challenging aspects of the business model typology.

\begin{tabular}{|c|c|c|c|c|}
\hline & Sustainable Challenges & $\begin{array}{c}\text { Business Model for } \\
\text { Maintenance-Focused Marinas }\end{array}$ & Business Model for Dock Marinas & $\begin{array}{l}\text { Business Model for Sport-Oriented } \\
\text { Marinas }\end{array}$ \\
\hline $\begin{array}{c}\text { Value } \\
\text { Proposition }\end{array}$ & $\begin{array}{ll}\text { - } & \text { Triple bottom line } \\
\text { - Integrating technology } \\
\text { innovation with business } \\
\text { model innovation }\end{array}$ & $\begin{array}{l}\text { - TBL attempted, though unbalanced } \\
\text { (economic priority) } \\
\text { - Technology innovation: A key role } \\
\text { for business model innovation } \\
\text { - Technology innovation for } \\
\text { environmental purposes }\end{array}$ & $\begin{array}{l}\text { TBL not envisaged and unbalanced } \\
\text { (economic priority) } \\
\text { - Technology innovation: not } \\
\text { determining business } \\
\text { model innovation }\end{array}$ & $\begin{array}{l}\text { TBL attempted, though unbalanced } \\
\text { (social priority) } \\
\text { - Technology innovation: Support for } \\
\text { business model innovation } \\
\text { - Technology innovation for } \\
\text { environmental purposes }\end{array}$ \\
\hline $\begin{array}{l}\text { Value } \\
\text { Creation }\end{array}$ & $\begin{array}{ll}\text { - } & \text { Mindset } \\
\text { - } & \text { Resources } \\
\text { - } & \text { Business modelling methods } \\
\text { and tools }\end{array}$ & $\begin{array}{l}\text { BM mindset: To increase revenues } \\
\text { by quality products and services } \\
\text { - Guiding light: Quality certificates } \\
\text { (e.g., ISO, Blue Flag) }\end{array}$ & $\begin{array}{l}\text { BM mindset: to guarantee revenues } \\
\text { - } \quad \text { Guiding a loyal market } \\
\text { - Steady market share }\end{array}$ & $\begin{array}{l}\text { BM mindset: To balance costs } \\
\text { with revenues } \\
\text { Guiding light: The impact of } \\
\text { societal benefits }\end{array}$ \\
\hline $\begin{array}{l}\text { Value } \\
\text { Capture }\end{array}$ & External relationships & $\begin{array}{l}\text { - Dense and unvaried net of } \\
\text { engaged stakeholders } \\
\text { - Network aim: Profit growth and } \\
\text { local development } \\
\text { - } \quad \text { Extra value for local community }\end{array}$ & $\begin{array}{l}\text { - Limited net of } \\
\text { engaged stakeholders } \\
\text { - } \quad \text { Network aim: Profit stability } \\
\text { - } \quad \text { Limited impact on local community }\end{array}$ & $\begin{array}{l}\text { - Dense and varied net of } \\
\text { engaged stakeholders } \\
\text { - Network aim: Joint collaboration } \\
\text { - Extra value for local community } \\
\text { and external beneficiaries }\end{array}$ \\
\hline
\end{tabular}


In regards to the value proposition, maintenance-focused marinas try to integrate TBL, even though they are oriented to economic aspects, which represent their main goal. Technology innovation plays a meaningful role in business model innovation, aiming for respect for the environment and pollution abatement. This emerging result recalls indeed the contribution of technological innovation in promoting smart tourism ecosystems as examined by Gretzel [78]. On the contrary, dock marinas lack co-creation of profits, social, and environmental benefits. As a consequence, TBL proves not to be integrated and appears as unbalanced, with the economic aspect prevailing. This finding is similar to the ones of Mihalič [74], Stylos and Vassiliadis [76], who detected difficulties in balancing the three dimensions of sustainability in the context of the hospitality sector, where the economic/financial dimension prevailed among the other dimensions. Moreover, the technology innovation is not influential for the business model innovation of this type. Sport-oriented marinas instead attempt to co-create profits and social benefits in an integrated way, though social aspects come first. Sport-oriented business model innovation is supported by the use of technologies, focused on environmental health. The results thus show that efforts to combine elements of the TBL perspective could lead to practical consequences in business model innovation towards sustainability, as outlined by Evans [31]; although the challenging aspect strongly undermines the ability of the company in not favoring one aspect among the others. In this challenge, the adoption of technology innovation seems to be a clue determinant for concurring to define the value proposition from the perspective of sustainability. This allowed us to formulate the following propositions:

Proposition 1. When defining a value proposition, a challenge for all SMEs is to balance the triple bottom line.

Proposition 2. When defining a value proposition, SMEs can integrate technology innovation with different degrees of importance depending on the business model.

In regards to these propositions on the value proposition, they are in line with the previous literature because recent studies $[74,76,77]$ recognized the difficulty of balancing TBL in the case of the hospitality sector. Nonetheless, we did not find authors that clearly state the adoption of technologies as a clue determinant of a sustainable business model in the case of tourism SMEs.

Concerning value creation, quality pushes maintenance-focused marinas to obtain revenues. Their main focus is the provision of high-quality products and services, guaranteed by the accomplishment of quality certificates and regulations. The mindset of dock marinas differs: They aim TO merely preserve their market share through customer loyalty, in order to maintain profit stability. Conversely, The main goal of sport-oriented marinas is to balance costs and revenues, guided by assuring an impact on societal benefits. The challenge of creating value from their business models is faced with different shades of sustainable effects. Every business model type shows a diverse interpretation within the business model mindset and diverse guiding principles. This allowed us to formulate the following propositions:

Proposition 3. When creating value, a challenge for SMEs is to fit their mindset, resources, and methods with their specific business model.

Proposition 3a. When creating value, SMEs that have a business model for sport-oriented marinas are more prone to social priorities.

In regards to these propositions on value creation, they are in line with previous literature on mindset and value creation in the business model [26,31,34,36,39]. Nonetheless, apart from the study of Høgevold [75], in the case of a hotel chain, in the literature we found a paucity of examples the on empirical examination of the importance of aligning strategy and operations in the case of sustainable business model innovation. Social priorities in business models have been detected mostly 
in destination management and the hospitality sector so far [79-82], neglecting their role in the case of other kinds of tourism SMEs.

Finally, even value capture responds to different mechanisms depending on each business model. Sustainable innovation factors through external relationships may indeed facilitate value capture from the perspective of sustainable business modelling [26,34,36]. Maintenance-focused marinas create a dense network of several stakeholders, which can significantly contribute to income growth. Local development may be achieved through the same relationships as well. Dock marinas confine themselves to the creation of a thin network of stakeholders. The unique purpose of this network is to increase profits. As a consequence, the local community can take advantage only in a limited way. The network of stakeholders created by sport-oriented marinas is dense and variegated. These marinas aim to jointly collaborate with a variety of stakeholders, creating extra-value dedicated not only to the local community but extended to external beneficiaries. The comparison among the three business model types shows different degrees in approaching sustainable business models, where just the sport-oriented group seems to be able to cause both internal value capture and external cascade value, adhering to the model of Morioka [34]. This allows us to formulate the following proposition:

Proposition 4. When capturing value, SMEs that have a business model for maintenance-focused or sport-oriented marinas are more prone to transfer value through external relationships.

In regards to this proposition on value capture, it is in line with the recent study of Morioka [34], which highlights both the direct value capture and the cascaded value. Still, we did not find any studies of which business models are more oriented to transfer value in the context of tourism SMEs.

\section{Conclusions}

The present work focused on the challenges faced by SMEs when they orient their business model toward sustainability. These challenges can have different natures, i.e., referring to strategy, innovation, capabilities and/or networks but they present similar characteristics if related to clusters of SMEs. The only common feature was the difficulty in balancing the three dimensions of sustainability.

The paper has academic implications because it continues the discourse on sustainable business models while taking a different perspective (the challenges) and two different contexts (SMEs and tourism). Moreover, it describes how the three dimensions of sustainable business models (i.e., value proposition, value creation, and value capture) can be merged concretely and discusses the challenges of a sustainable business model and finding business model types where challenges present similar characteristics.

The paper has practical implications, i.e., the different types give hints to managers of yacht tourism enterprises and in general to managers of SMEs that can recognize their company as adhering to a business model type and can take hints from their story related to a sustainable business model.

The authors acknowledge a limitation due to the explorative aim of the study. Thus, the limited set of cases could show industry-dependent features, which could not be generalized to an overall discussion on service companies. Nonetheless, given the theoretical gap detected by the literature review, the contributions of this research can be seen as a first step towards the development of further empirical studies on business model sustainability in SMEs. Future research could indeed develop a cross-sectoral comparison in order to trace paths to support business model sustainability, either within the broadest context of subsectors of the service industry or among different industries of both manufacture and service. Promoting extensive research on the field of SMEs business models could provide SME owners and managers new tools for understanding market dynamics and opportunities to improve their business. Finally, academics could apply a multi-method research design to detect, test, and improve business model features of SMEs.

Author Contributions: All authors contributed equally to this work. All authors wrote, reviewed, and commented on the manuscript. All authors have read and approved the final manuscript. 
Funding: This research was funded by the iBLUE Project, Interreg Mediterranean Programme. The project was co-financed by the European Regional Development Fund.

Acknowledgments: The authors thank the partners of the iBLUE Project RCDI-Portugal, the Chamber of Commerce of Sevilla and the Chamber of Commerce of Durres for their support in the local interviews. The authors are grateful to the three blind reviewers for their comments, which improved the work presentation.

Conflicts of Interest: The authors declare no conflict of interest.

\section{References}

1. United Nations. Transforming Our World: The 2030 Agenda for Sustainable Development. Available online: https://sustainabledevelopment.un.org/content/documents/21252030\%20Agenda\% 20for\%20Sustainable\%20Development\%20web.pdf (accessed on 3 August 2018).

2. OECD. Sustainable Development. Linking Economy, Society, Environment. Available online: https://www. oecd-ilibrary.org/environment/sustainable-development_9789264055742-en (accessed on 3 August 2018).

3. European Commission. Annual Report on European SMEs. Available online: https://ec.europa.eu/growth/ smes/business-friendly-environment/performance-review_en?pk_source=ec_newsroom\&pk_medium= link\&pk_campaign=spr17\#annual-report (accessed on 3 August 2018).

4. Moore, S.B.; Manring, S.L. Strategy development in small and medium sized enterprises for sustainability and increased value creation. J. Clean. Prod. 2009, 17, 276-282. [CrossRef]

5. Revell, A.; Stokes, D.; Chen, H. Small businesses and the environment: Turning over a new leaf? Bus. Strategy Environ. 2010, 19, 273-288. [CrossRef]

6. Hörisch, J.; Johnson, M.P.; Schaltegger, S. Implementation of sustainability management and company size: A knowledge-based view. Bus. Strategy Environ. 2015, 24, 765-779. [CrossRef]

7. Jansson, J.; Nilsson, J.; Modig, F.; Hed Vall, G. Commitment to sustainability in small and medium-sized enterprises: The influence of strategic orientations and management values. Bus. Strategy Environ. 2017, 26, 69-83. [CrossRef]

8. Shankar, K.M.; Kannan, D.; Kumar, P.U. Analyzing sustainable manufacturing practices-A case study in Indian context. J. Clean. Prod. 2017, 164, 1332-1343. [CrossRef]

9. Chassé, S.; Boiral, O. Legitimizing corporate (un) sustainability: A case study of passive SMEs. Organ. Environ. 2017, 30, 324-345. [CrossRef]

10. Schmidt, F.C.; Zanini, R.R.; Korzenowski, A.L.; Junior, R.S.; do Nascimento, K.B.X. Evaluation of Sustainability Practices in Small and Medium-Sized Manufacturing Enterprises in Southern Brazil. Sustainability 2018, 10, 2460. [CrossRef]

11. Del Brìo, J.A.; Junquera, B. A review of the literature on environmental innovation management in SMEs: Implications for public policies. Technovation 2003, 23, 939-948. [CrossRef]

12. Santos, M. CSR in SMEs: Strategies, practices, motivations and obstacles. Soc. Responsib. J. 2011, 7, 490-508. [CrossRef]

13. Lepoutre, J.; Heene, A. Investigating the impact of firm size on small business social responsibility: A critical review. J. Bus. Ethics 2006, 67, 257-273. [CrossRef]

14. Johnson, M.P.; Schaltegger, S. Two decades of sustainability management tools for SMEs: How far have we come? J. Small Bus. Manag. 2016, 54, 481-505. [CrossRef]

15. Hillary, R. Environmental management systems and the smaller enterprise. J. Clean. Prod. 2004, 12, 561-569. [CrossRef]

16. MCEwen, T. An examination of the barriers that impact the implementation of environmental sustainability practices in small businesses. J. Bus. Entrep. 2013, 25, 117.

17. Hsu, C.; An-Yuan, C.; Wei, L. Identifying key performance factors for sustainability development of SMEs-integrating QFD and fuzzy MADM methods. J. Clean. Prod. 2017, 161, 629-645. [CrossRef]

18. Arevalo, J.A.; Castelló, I.; de Colle, S.; Lenssen, G.; Neumann, K.; Zollo, M. Introduction to the special issue: Integrating sustainability in business models. J. Manag. Dev. 2011, 30, 941-954. [CrossRef]

19. Svensson, G.; Wagner, B. Transformative business sustainability: Multi-layer model and network of e-footprint sources. Eur. Bus. Rev. 2011, 23, 334-352. [CrossRef]

20. Schaltegger, S.; Lüdeke-Freund, F.; Hansen, E.G. Business models for sustainability: A co-evolutionary analysis of sustainable entrepreneurship, innovation, and transformation. Organ. Environ. 2016, 29, 264-289. [CrossRef] 
21. Buffa, F.; Franch, M.; Rizio, D. Environmental management practices for sustainable business models in small and medium sized hotel enterprises. J. Clean. Prod. 2018, 194, 656-664. [CrossRef]

22. Piscicelli, L.; Ludden, G.D.S.; Cooper, T. What makes a sustainable business model successful? An empirical comparison of two peer-to-peer goods-sharing platforms. J. Clean. Prod. 2018, 172, 4580-4591. [CrossRef]

23. Geissdoerfer, M.; Vladimirova, D.; Evans, S. Sustainable business model innovation: A review. J. Clean. Prod. 2018. [CrossRef]

24. Schaltegger, S.; Lüdeke-Freund, F.; Hansen, E.G. Business cases for sustainability: The role of business model innovation for corporate sustainability. Int. J. Innov. Sustain. Dev. 2012, 6, 95-119. [CrossRef]

25. Bocken, N.; Short, S.; Rana, P.; Evans, S. A value mapping tool for sustainable business modelling. Corp. Gov. 2013, 13, 482-497. [CrossRef]

26. Boons, F.; Lüdeke-Freund, F. Business models for sustainable innovation: State-of-the-art and steps towards a research agenda. J. Clean. Prod. 2013, 45, 9-19. [CrossRef]

27. Abdelkafi, N.; Täuscher, K. Business models for sustainability from a system dynamics perspective. Organ. Environ. 2016, 29, 74-96. [CrossRef]

28. Hart, S.L.; Milstein, M.B. Creating sustainable value. Acad. Manag. Perspect. 2003, 17, 56-67. [CrossRef]

29. Elkington, J. Cannibals with Forks-Triple Bottom Line of 21st Century Business; New Society Publishers: Stoney Creek, CT, USA, 1997.

30. Elkington, J. Enter the triple bottom line. In The Triple Bottom Line: Does It All Add Up? Henriques, A., Richardson, J., Eds.; Earthscan: London, UK, 2004; pp. 1-16.

31. Evans, S.; Vladimirova, D.; Holgado, M.; Van Fossen, K.; Yang, M.; Silva, E.A.; Barlow, C.Y. Business model innovation for sustainability: Towards a unified perspective for creation of sustainable business models. Bus. Strategy Environ. 2017, 26, 597-608. [CrossRef]

32. Adams, R.; Bessant, J.; Jeanrenaud, S.; Overy, P.; Denyer, D. Innovating for Sustainability. A Systematic Review of the Body of Knowledge; Network for Business Sustainability: London, ON, Canada, 2012.

33. Richardson, J. The business model: An integrative framework for strategy execution. Strat. Chang. 2008, 17, 133-144. [CrossRef]

34. Morioka, S.N.; Bolis, I.; Monteiro de Carvalho, M. From an ideal dream towards reality analysis: Proposing Sustainable Value Exchange Matrix (SVEM) from systematic literature review on sustainable business models and face validation. J. Clean. Prod. 2018, 178, 76-88. [CrossRef]

35. Van Bommel, K. Managing tensions in sustainable business models: Exploring instrumental and integrative strategies. J. Clean. Prod. 2018. [CrossRef]

36. Bocken, N.M.P.; Short, S.W.; Rana, P.; Evans, S. A literature and practice review to develop sustainable business model archetypes. J. Clean. Prod. 2014, 65, 42-56. [CrossRef]

37. Heyes, G.; Sharmina, M.; Mendoza, J.M.F.; Gallego-Schmid, A.; Azapagic, A. Developing and implementing circular economy business models in service-oriented technology companies. J. Clean. Prod. 2018, 177, 621-632. [CrossRef]

38. Joyce, A.; Paquin, R.L. The triple layered business model canvas: A tool to design more sustainable business models. J. Clean. Prod. 2016, 135, 1474-1486. [CrossRef]

39. Stubbs, W.; Cocklin, C. Conceptualizing a 'sustainability business model'. Organ. Environ. 2008, $21,103-127$. [CrossRef]

40. Wells, P. Degrowth and techno-business model innovation: The case of Riversimple. J. Clean. Prod. 2016, 197, 1704-1710. [CrossRef]

41. Yu, D.; Hang, C.C. A reflective review of disruptive innovation theory. Int. J. Manag. Rev. 2010, 12, 435-452. [CrossRef]

42. Zott, C.; Amit, R.; Massa, L. The business model: Recent developments and future research. J. Manag. 2011, 37, 1019-1042. [CrossRef]

43. Björkdahl, J.; Holmén, M. Editorial: Business model innovation-the challenges ahead. Int. J. Prod. Dev. 2013, 18, 213-225.

44. Chesbrough, H. Business model innovation: Opportunities and barriers. Long Range Plan. 2010, 43, $354-363$. [CrossRef]

45. Dentchev, N.; Rauter, R.; Jóhannsdóttir, L.; Snihur, Y.; Rosano, M.; Baumgartner, R.; Nyberg, T.; Tang, X.; van Hoof, B.; Jonker, J. Embracing the variety of sustainable business models: A prolific field of research and a future research agenda. J. Clean. Prod. 2018, 194, 695-703. [CrossRef] 
46. Geissdoerfer, M.; Bocken, N.M.; Hultink, E.J. Design thinking to enhance the sustainable business modelling process-A workshop based on a value mapping process. J. Clean. Prod. 2016, 135, 1218-1232. [CrossRef]

47. Girotra, K.; Netessine, S. OM forum-Business model innovation for sustainability. Manuf. Serv. Oper. Manag. 2013, 15, 537-544. [CrossRef]

48. Halme, M.; Korpela, M. Responsible innovation toward sustainable development in small and medium-sized enterprises: A resource perspective. Bus. Strategy Environ. 2014, 23, 547-566. [CrossRef]

49. Lüdeke-Freund, F.; Carroux, S.; Joyce, A.; Massa, L.; Breuer, H. The sustainable business model pattern taxonomy-45 patterns to support sustainability-oriented business model innovation. Sustain. Prod. Consum. 2018, 15, 145-162. [CrossRef]

50. Johnson, M.W.; Christensen, C.M.; Kagermann, H. Reinventing your business model. Harv. Bus. Rev. 2008, 86, 51-59.

51. Yang, M.; Vladimirova, D.; Rana, P.; Evans, S. Sustainable value analysis tool for value creation. Asian J. Manag. Sci. Appl. 2014, 1, 312-332. [CrossRef]

52. Dembek, K.; York, J.; Singh, P.J. Creating value for multiple stakeholders: Sustainable business models at the Base of the Pyramid. J. Clean. Prod. 2018, 196, 1600-1612. [CrossRef]

53. Vladimirova, D. Transformation of Traditional Manufacturers towards Servitized Organisations. Ph.D. Thesis, Cranfield University, Bedford, UK, 2012.

54. Depken, D.; Zeman, C. Small business challenges and the triple bottom line, TBL: Needs assessment in a Midwest State, USA. Technol. Forecast. Soc. Chang. 2017. [CrossRef]

55. ICTSD. Services and Sustainable Development. A Conceptual Approach; International Centre for Trade and Sustainable Development: Geneva, Switzerland, 2016.

56. Kozlowski, A.; Searcy, C.; Bardecki, M. The reDesign canvas: Fashion design as a tool for sustainability. J. Clean. Prod. 2018, 183, 194-207. [CrossRef]

57. Gasbarro, F.; Rizzi, F.; Frey, M. Sustainable institutional entrepreneurship in practice: Insights from SMEs in the clean energy sector in Tuscany (Italy). Int. J. Entrep. Behav. Res. 2018, 24, 476-498. [CrossRef]

58. Tang, L.; Murphree, M.; Breznitz, D. Structured uncertainty: A pilot study on innovation in China's mobile phone handset industry. J. Technol. Transf. 2016, 41, 1168-1194. [CrossRef]

59. Bocken, N.M.P. Sustainable venture capital-catalyst for sustainable start-up success? J. Clean. Prod. 2015, 108, 647-658. [CrossRef]

60. Goyal, S.; Sergi, B.S.; Kapoor, A. Understanding the key characteristics of an embedded business model for the base of the pyramid markets. Econ. Sociol. 2014, 7, 26-40. [CrossRef] [PubMed]

61. Funkhouser, E.; Blackburn, G.; Magee, C.; Rai, V. Business model innovations for deploying distributed generation: The emerging landscape of community solar in the US. Energy Res. Soc. Sci. 2015, 10, 90-101. [CrossRef]

62. Gsodam, P.; Rauter, R.; Baumgartner, R.J. The renewable energy debate: How Austrian electric utilities are changing their business models. Energy Sustain. Soc. 2015, 5-28. [CrossRef]

63. Hannon, M.J.; Foxon, T.J.; Gale, W.F. 'Demand pull'government policies to support Product-Service System activity: The case of Energy Service Companies (ESCos) in the UK. J. Clean. Prod. 2015, 108, 900-915. [CrossRef]

64. Bolton, R.; Hannon, M. Governing sustainability transitions through business model innovation: Towards a system understanding. Res. Policy 2016, 45-49, 1731-1742. [CrossRef]

65. Breuer, H.; Lüdeke-Freund, F. Values-based network and business model innovation. Int. J. Innov. Manag. 2017, 21. [CrossRef]

66. Gaspari, M.; Lorenzoni, A.; Frías, P.; Reneses, J. Integrated Energy Services for the industrial sector: An innovative model for sustainable electricity supply. Util. Policy 2017, 45, 118-127. [CrossRef]

67. Giannoutakis, K.N.; Li, F. Making a business case for intelligent transport systems: A holistic business model framework. Transp. Rev. 2012, 32, 781-804. [CrossRef]

68. Heinz, S.; O'Connell, J.F. Air transport in Africa: Toward sustainable business models for African airlines. J. Transp. Geogr. 2013, 31, 72-83. [CrossRef]

69. Corbo, L. In search of business model configurations that work: Lessons from the hybridization of Air Berlin and JetBlue. J. Air Transp. Manag. 2017, 64, 139-150. [CrossRef] 
70. Dreyer, B.; Lüdeke-Freund, F.; Hamann, R.; Faccer, K. Upsides and downsides of the sharing economy: Collaborative consumption business models' stakeholder value impacts and their relationship to context. Technol. Forecast. Soc. Chang. 2017, 125, 87-104. [CrossRef]

71. Esposito, M.; Kapoor, A.; Goyal, S. Enabling healthcare services for the rural and semi-urban segments in India: When shared value meets the bottom of the pyramid. Corp. Gov. Int. J. Bus. Soc. 2012, 12, 514-533. [CrossRef]

72. Bonća, P.D.; Tajnikar, M. Measuring the impact of innovations on efficiency in complex hospital settings. South East Eur. J. Econ. Bus. 2015, 10, 45-54. [CrossRef]

73. Angeli, F.; Jaiswal, A.K. Business model innovation for inclusive health care delivery at the bottom of the pyramid. Organ. Environ. 2016, 29, 486-507. [CrossRef]

74. Mihalič, T.; Žabkar, V.; Knežević Cvelbar, L. A hotel sustainability business model: Evidence from Slovenia. J. Sustain. Tour. 2012, 20, 701-719. [CrossRef]

75. Høgevold, N.M.; Svensson, G.; Padin, C. A sustainable business model in services: An assessment and validation. Int. J. Qual. Serv. Sci. 2015, 7, 17-33. [CrossRef]

76. Stylos, N.; Vassiliadis, C. Differences in sustainable management between four-and five-star hotels regarding the perceptions of three-pillar sustainability. J. Hosp. Mark. Manag. 2015, 24, 791-825. [CrossRef]

77. Melissen, F.; Cavagnaro, E.; Damen, M.; Düweke, A. Is the hotel industry prepared to face the challenge of sustainable development? J. Vacat. Mark. 2016, 22, 227-238. [CrossRef]

78. Gretzel, U.; Werthner, H.; Koo, C.; Lamsfus, C. Conceptual foundations for understanding smart tourism ecosystems. Comput. Hum. Behav. 2015, 50, 558-563. [CrossRef]

79. Jaafar, M.; Maideen, S.A. Ecotourism-related products and activities, and the economic sustainability of small and medium island chalets. Tour. Manag. 2012, 33, 683-691. [CrossRef]

80. Peric, M.; Djurkin, J. Systems thinking and alternative business model for responsible tourist destination. Kybernetes 2014, 43, 480-496. [CrossRef]

81. Cannas, R. The Sustainable Tourism Management of Cultural Heritage: The Case of the Rosas Mine in Sardinia. Almatour.-J. Tour. Cult. Territ. Dev. 2016, 7, 38-59. [CrossRef]

82. Zebryte, I.; Jorquera, H. Chilean tourism sector "B Corporations": Evidence of social entrepreneurship and innovation. Int. J. Entrep. Behav. Res. 2017, 23, 866-879. [CrossRef]

83. Yang, Z.; Cai, J.; Sliuzas, R. Agro-tourism enterprises as a form of multi-functional urban agriculture for peri-urban development in China. Habitat Int. 2010, 34, 374-385. [CrossRef]

84. Broccardo, L.; Culasso, F.; Truant, E. Unlocking value creation using an agritourism business model. Sustainability 2017, 9, 1618. [CrossRef]

85. Voss, C.; Tsikriktsis, N.; Frohlich, M. Case research in operations management. Int. J. Oper. Prod. Manag. 2002, 22, 195-219. [CrossRef]

86. Pettigrew, A.M. The character and significance of strategy process research. Strat. Manag. J. 1992, 13, 5-16. [CrossRef]

87. McCutcheon, D.M.; Meredith, J.R. Conducting case study research in operations management. J. Oper. Manag. 1993, 11, 239-256. [CrossRef]

88. Yin, R.K. Case Study Research Design and Methods, 3rd ed.; Sage: London, UK, 2003.

89. Patton, M.Q. Qualitative Evaluation Methods; Sage Publications: Beverly Hills, CA, USA, 2002.

90. Gioia, D.A.; Corley, K.G.; Hamilton, A.L. Seeking qualitative rigor in inductive research: Notes on the Gioia methodology. Organ. Res. Methods 2012, 16, 15-31. [CrossRef]

91. Eisenhardt, K.M.; Graebner, M.E. Theory building from cases: Opportunities and challenges. Acad. Manag. J. 2007, 50, 25-32. [CrossRef]

92. Wallendorf, M.; Belk, R.W. Assessing trustworthiness in naturalistic consumer research. In Interpretive Consumer Research; Hirschman, E.C., Ed.; Association for Consumer Research: Provo, UT, USA, 1989; pp. 69-84.

93. Eisenhardt, K.M. Building theories from case study research. Acad. Manag. Rev. 1989, 14, 532-550. [CrossRef]

94. Miles, M.B.; Huberman, A.M. Qualitative Data Analysis: An Expanded Source Book, 2nd ed.; Sage Publications: London, UK, 1994.

(C) 2018 by the authors. Licensee MDPI, Basel, Switzerland. This article is an open access article distributed under the terms and conditions of the Creative Commons Attribution (CC BY) license (http:// creativecommons.org/licenses/by/4.0/). 